\title{
Isochromosome 13 in a patient with childhood- onset schizophrenia, ADHD, and motor tic disorder
}

Sharon L Graw ${ }^{1 *}$, Karen Swisshelm² ${ }^{2}$ Kirsten Floyd ${ }^{1}$, Billie J Carstens ${ }^{2}$, Marianne Z Wamboldt ${ }^{1,3}$, Randall G Ross ${ }^{1}$ and Sherry Leonard ${ }^{1,4}$

\begin{abstract}
Background: A small percentage of all cases of schizophrenia have a childhood onset. The impact on the individual and family can be devastating. We report the results of genetic analyses from a patient with onset of visual hallucinations at 5 years, and a subsequent diagnosis at 9 years of schizophrenia, attention deficit hyperactivity disorder (ADHD) with hyperactivity and impulsivity, and chronic motor tic disorder.

Results: Karyotypic analysis found 45,XX,i(13)(q10) in all cells examined. Alpha satellite FISH of isochromosome 13 revealed a large unsplit centromeric region, interpreted as two centromeres separated by minimal or undetectable short-arm material or as a single monocentric centromere, indicating that the isochromosome likely formed postzygotically by a short arm U-type or centromeric exchange. Characterization of chromosome 13 simple tandem repeats and Affymetrix whole-genome 6.0 SNP array hybridization found homozygosity for all markers, and the presence of only a single paternal allele in informative markers, consistent with an isodisomic isochromosome of paternal origin. Analysis of two chromosome 13 schizophrenia candidate genes, D-amino acid oxidase activator $(D A O A)$ and 5-hydroxytryptamine (serotonin) receptor 2A (5-HTR2A), failed to identify non-synonymous coding mutations but did identify homozygous risk polymorphisms.

Conclusions: We report a female patient with childhood-onset schizophrenia, ADHD, and motor tic disorder associated with an isodisomic isochromosome 13 of paternal origin and a 45,XX,i(13)(q10q10) karyotype. We examined two potential mechanisms to explain chromosome 13 involvement in the patient's pathology, including reduction to homozygosity of a paternal mutation and reduction to homozygosity of a paternal copy number variation, but were unable to identify any overtly pathogenic abnormality. Future studies may consider whether epigenetic mechanisms resulting from uniparental disomy (UPD) and the lack of chromosome 13 maternal alleles lead to the patient's features.
\end{abstract}

Keywords: Attention deficit hyperactivity disorder, Chromosome 13, Isochromosome, Schizophrenia, childhood

\section{Background}

Schizophrenia affects approximately $1 \%$ of the general population [1]. While symptoms of the disorder generally manifest themselves in the late teens or twenties, they appear before the age of 18 years in approximately $4 \%$ of cases [2] and have been reported as early as 3 years [3]. Features of childhood-onset schizophrenia are

\footnotetext{
* Correspondence: Sharon.Graw@ucdenver.edu

'Department of Psychiatry, University of Colorado School of Medicine,

Aurora, CO, USA

Full list of author information is available at the end of the article
}

typically more severe than found in the adult-onset form of the disease, and affected children exhibit auditory hallucinations and delusions, accompanied by a flattened affect, deficits of speech and language, motor development, attention and memory, and social fluency as well as reduced cognitive performance [4]. Long-term outcomes for children with schizophrenia may be worse than adult-onset cases, with continued risk of morbidity [4].

Adult-onset schizophrenia is considered a neurodevelopmental disorder resulting from the interaction of a

\section{Biomed Central}


genetic predisposition with environmental factors. Considerable effort has been put forth to identify genes associated with schizophrenia, and multiple predisposing genes have been identified, including CHRNA7 [5], DAOA [6], COMT, DTNBP1, NRG1, DISC1, GRM3, and $P R O D H$ [7]. In the last several years, Genome-Wide Association Studies (GWAS) have led to many newly identified schizophrenia susceptibility loci, including the major histocompatibility complex, $C A C N A 1 C$, the ITIH3-ITIH4 region, ZNF804A, PLAA, ANK3, and others [8-21]. Challenges to these studies include modest effects of individual variations, as well as lack of interstudy reproducibility. Genomic copy number variation (CNV) studies have revealed several regions of duplication/deletion, including a recurrent deletion of $22 \mathrm{q} 11.2$ and microdeletions of $1 \mathrm{q} 21.1,15 \mathrm{q} 11.2,15 \mathrm{q} 13.3$, and a microduplication of $16 \mathrm{p} 11.2$ [22-25], with most CNVs having a spectrum of pathologic features and showing evidence of overlap with other forms of brain disorder. Environmental factors that are associated with an increased risk of developing schizophrenia include exposure to stress in utero [26], low socioeconomic status [27], urbanicity [28], and cannabis use [29].

Only a few genetic studies have been undertaken to specifically identify genes leading to the development and pathology of childhood-onset schizophrenia. Associations have been reported with $D A O A$ [30], NRG1 [31], DTNBP1 [32,33], and GAD1 [34]. Addington and Rapoport [35] found that approximately $10 \%$ of childhood-onset schizophrenia patients in their cohort had cytogenetic abnormalities, including deletions of 22q11, atypical/mosaic 45,X and 47,XXX, recurrent duplications of 16p11.2 and MYT1L (mapped to 2p25.3), and deletion of NRXN1 (on 2p16.3), all of which have been reported in adult-onset schizophrenia patients. Thus, there appears to be considerable overlap of purported candidate regions between adult and childhood-onset schizophrenia, indicating the potential perturbation of similar developmental pathways.

Here we report on a patient with onset schizophrenia symptoms at age 5 years, and a subsequent diagnosis at 9 years of childhood-onset schizophrenia, attention deficit hyperactivity disorder (ADHD) with hyperactivity and impulsivity, and chronic motor tic disorder. Cytogenetic and molecular analyses demonstrate that this patient carries an isodisomic isochromosome 13 of paternal origin.

\section{Case Presentation}

The female patient presented to the study team at 9 years of age. Diagnoses were best estimate diagnoses based on DSM-IV [1], determined after completion of a semi-structured diagnostic interview of both the parents and child [36]. Using a non-hierarchical diagnostic approach, the subject met diagnostic criteria for schizophrenia, attention deficit hyperactivity disorder (hyperactivity/impulsivity subtype), and chronic motor tic disorder. Pregnancy history was unremarkable, and delivery was at term via planned caesarean section secondary to breach presentation. Early milestones were delayed, and the patient underwent a developmental evaluation at $21 / 2$ year of age. Academically, the patient has repeated grades and is currently in a special needs program with some mainstreamed class time.

The patient first reported visual hallucinations at 5 years, and by 7 years psychotic symptoms included frequent visual hallucinations, command auditory hallucinations, and grandiose beliefs about superhuman powers. Patient symptoms described by the parents included flat affect, periods of incoherence, and loosening of associations. All symptoms were present consistently for $21 / 2$ years prior to study enrollment. The patient is under treatment with risperidone and amantadine and is able to manage behavior during the day. Her attention span is reported to be difficult but improved with treatment. She still experiences auditory hallucinations which are now ego dystonic and identifiable. In addition, the patient has underdeveloped social skills and has developed relapsing and remitting vocal tics, as well as simple and complex motor tics.

Family history includes a maternal great grandmother with recurrent psychiatric inpatient admissions, but insufficient information was available for the study team to clarify diagnosis. The patient's mother had a history of depressive symptoms.

\section{Results \\ Cytogenetics}

Karyotypic analysis of twenty G-banded metaphases from mitogen stimulated peripheral blood lymphocytes was performed at the 450-650 band level. Analysis revealed 45 chromosomes in each cell examined, with a Robertsonian-type translocation of the long arms of each homologue of chromosome 13 (Figures 1a and 1b). The patient initially had a reported karyotype of 45, XX, $\operatorname{der}(13 ; 13)(q 10 ; q 10)$ which subsequently was modified to 45 ,XX,i(13)(q10) upon molecular characterization.

\section{Fluorescence In Situ Hybridization (FISH)}

Centromere status was determined by FISH analysis with an alpha satellite probe homologous to the centromeric regions of chromosomes 13 and 21 (Figures 1c and 1d) which showed the presence of a large, chromosome 13 centromere. This was interpreted as either two centromeres separated by minimal or undetectable short-arm material or as a single, large chromosome 13 centromere. Paternal and maternal cytogenetic analyses revealed normal karyotypes. 


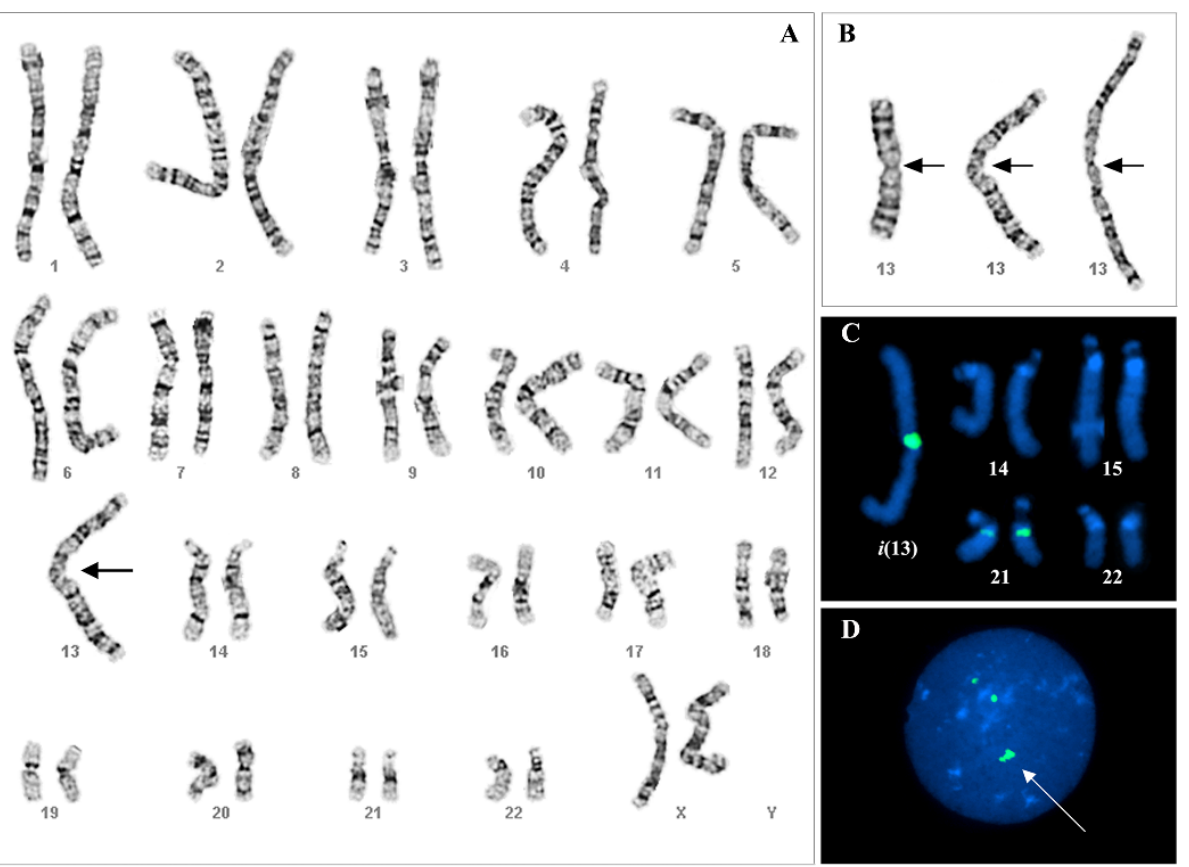

Figure 1 Cytogenetic analysis of patient. A) 45,XX,i(13)(q10) chromosomal karyotype of proband, showing the presence of a single metacentric chromosome consisting of two copies of the patient's chromosome 13 joined at the centromere (arrow), B) Composite of derivative 13 homologues from three metaphase spreads with centromeres indicated by arrows, C) Composite of acrocentric homologues hybridized with alpha satellite DNA probe for centromeres of chromosomes 13 and 21, demonstrating the presence of a large centromere on the

isochromosome 13, D) Interphase cell with alpha satellite DNA probe for centromeres of chromosomes 13 and 21. Arrow points to large likely signal of the isochromosome 13 .

Since there is a reported association between schizophrenia and deletions in chromosome 22q11.2 [37], this region underwent examination in the patient and her parents. FISH analysis in the DiGeorge/Velocardiofacial syndrome critical region at chromosome 22q11.2 with the DiGeorge/VCFS Tuple1 probe did not identify any deletion or duplication in the patient or her parents in this region on chromosome 22 .

\section{Simple tandem repeats}

Because of the initial finding of the patient's der $(13 ; 13)$ (q10;q10), the chromosome 13 content of the patient and her parents underwent characterization with twelve simple tandem repeats (STRs) spanning chromosome 13 plus a control STR from chromosome 21 . The patient was homozygous for all chromosome 13 STRs (Table 1). In six STRs, the patient had only paternal alleles, with lack of detectable maternal alleles. Five of these STRs were completely informative, the patient inheriting only a single paternal allele when the father was heterozygous. Based on these STRs, we were able to conclude that the patient carried alleles from only a single paternal chromosome 13, and thus had an isodisomic isochromosome 13 accompanied by a karyotype of 45,XX,i (13)(q10). The remaining six STRs of the twelve examined were less informative, and while the patient was homozygous at these STRs, the pattern was consistent with either paternal or maternal inheritance.

\section{Affymetrix Whole-Genome Human SNP 6.0 microarrays} In order to further refine the patient's chromosome 13 status, DNA from the patient and her parents were utilized for Affymetrix whole genome Human SNP 6.0 microarray evaluation. Allele analysis demonstrated that the patient was homozygous for all of chromosome 13 (Figure 2). In contrast, both paternal and maternal DNA demonstrated chromosome 13 heterozygosity. Chromosome $13 \mathrm{CNV}$ status was examined, and the patient was found to have minimal evidence of deletions or duplications [Additional File 1]. Of the nine regions of duplication/deletion that were identified on chromosome 13, none reached default criteria required for identification as a CNV segment (Minimum 100,000 bp or 50 markers for gain/loss) with any degree of certainty. Five were not located in any gene, and four were located in genes (ATP8A2, LHFP, PHF11, RCBTB1, and PIBF1 (C13orf24)) not yet shown to be associated with schizophrenia. Thus, of the five chromosome 13 genes with evidence of duplication or deletion in the patient, none appears to be candidates for her pathology. While not 
Table 1 STR analysis of patient and her parents

\begin{tabular}{|c|c|c|c|c|}
\hline Marker & Position & Subject & Genotype & Inheritance \\
\hline \multirow[t]{3}{*}{$\mathrm{D} 13 \mathrm{~S} 175$} & $1,653,855$ & Patient & $1 / 1$ & Homozygous, $\mathrm{P}$ \\
\hline & & Father & $1 / 2$ & \\
\hline & & Mother & $3 / 4$ & \\
\hline \multirow[t]{3}{*}{ D13S171 } & $14,064,951$ & Patient & $1 / 1$ & Homozygous, $\mathrm{M}$ or $\mathrm{P}$ \\
\hline & & Father & $1 / 1$ & \\
\hline & & Mother & $1 / 2$ & \\
\hline \multirow[t]{3}{*}{ D13S218 } & $19,831,225$ & Patient & $1 / 1$ & Homozygous, $\mathrm{M}$ or $\mathrm{P}$ \\
\hline & & Father & $1 / 2$ & \\
\hline & & Mother & $1 / 1$ & \\
\hline \multirow[t]{3}{*}{ D13S155 } & $34,882,886$ & Patient & $1 / 1$ & Homozygous, $\mathrm{M}$ or $\mathrm{P}$ \\
\hline & & Father & $1 / 2$ & \\
\hline & & Mother & $1 / 3$ & \\
\hline \multirow[t]{3}{*}{ D13S176 } & $41,205,385$ & Patient & $1 / 1$ & Homozygous, P \\
\hline & & Father & $1 / 2$ & \\
\hline & & Mother & $1 / 3$ & \\
\hline \multirow[t]{3}{*}{ D13S71 } & $75,575,535$ & Patient & $1 / 1$ & Homozygous, P \\
\hline & & Father & $1 / 1$ & \\
\hline & & Mother & $2 / 2$ & \\
\hline \multirow[t]{3}{*}{ D13S154 } & $76,860,260$ & Patient & $1 / 1$ & Homozygous, P \\
\hline & & Father & $1 / 2$ & \\
\hline & & Mother & $3 / 4$ & \\
\hline \multirow[t]{3}{*}{ D13S174 } & $102,954,076$ & Patient & $1 / 1$ & Homozygous, $\mathrm{M}$ or $\mathrm{P}$ \\
\hline & & Father & $1 / 2$ & \\
\hline & & Mother & $1 / 3$ & \\
\hline \multirow[t]{3}{*}{ D13S1809 } & $106,132,754$ & Patient & $1 / 1$ & Homozygous, P \\
\hline & & Father & $1 / 2$ & \\
\hline & & Mother & $2 / 3$ & \\
\hline \multirow[t]{3}{*}{ D13S173 } & $107,806,947$ & Patient & $1 / 1$ & Homozygous, $\mathrm{M}$ or $\mathrm{P}$ \\
\hline & & Father & $1 / 2$ & \\
\hline & & Mother & $1 / 1$ & \\
\hline \multirow[t]{3}{*}{ D13S1265 } & $109,328,688$ & Patient & $1 / 1$ & Homozygous, P \\
\hline & & Father & $1 / 2$ & \\
\hline & & Mother & $2 / 3$ & \\
\hline \multirow[t]{3}{*}{ D13S1295 } & $113,094,472$ & Patient & $1 / 1$ & Homozygous, $\mathrm{M}$ or $\mathrm{P}$ \\
\hline & & Father & $1 / 2$ & \\
\hline & & Mother & $1 / 1$ & \\
\hline \multirow[t]{3}{*}{ D21S270 } & & Patient & $1 / 2$ & \\
\hline & & Father & $1 / 2$ & \\
\hline & & Mother & $2 / 3$ & \\
\hline
\end{tabular}

Chromosome 13 and 21 markers, along with position on chromosome (ensembl.org). Alleles were assigned arbitrary numbers, and genotype information is given for the patient and parents. Inheritance patterns have been determined. $P$ indicates paternal inheritance and $M$ indicates maternal inheritance. Bolded inheritance patterns demonstrate the expression of a single paternal allele and no maternal alleles in the patient, when the father is heterozygous.

currently associated with schizophrenia, these genes may be investigated in future studies of this patient.

Several other regions of the genome associated with CNVs in schizophrenia were examined, including chromosome 22 (Figure 3), which is implicated in childhood onset schizophrenia [35], and chromosome 15 (Figure 4), demonstrated to have copy number variations in patients with schizophrenia [22]. While the patient and her mother did have a small duplication on chromosome 22 (Figure 3 ), there was no evidence of deletions in the region implicated in 22q11.2 Deletion Syndrome. The patient and her father both had a deletion on chromosome 15 distal to the CHRNA7 gene, encoding the $\alpha 7^{*}$ nicotinic receptor (Figure 4a). The patient's mother had a chromosome 15 duplication of the CHRFAM7A gene (Figure 4b), which is also associated with schizophrenia [38,39] and modulates $\alpha 7^{*}$ nicotinic receptor activity $[40,41]$. While it is possible that the patient's prenatal environment contained perturbations in nicotinic receptor activity, it seems unlikely that chromosome $15 \mathrm{CNVs}$ in this family can account for the patient's severe pathology. No CNVs were found in the regions encoding NRXN1 and MYT1L on chromosome 2 [Additional file 2]. Analysis of chromosome 16p11.2 in our patient reveals no significant regions of duplication or deletion. However, the proband and her parents contain regions of $\mathrm{LOH}$ on chromosome 16p11.2 [Additional file $3]$. Since the patient's chromosome $16 \mathrm{LOH}$ is recapitulated in her parents, it is unlikely to be involved in the patient's pathology.

\section{Gene Analysis}

Multiple genes encoded by chromosome 13 have been suggested to contribute to schizophrenia susceptibility, including DAOA [42], 5-HTR2A [43], KPNA3 and KPNB3 [44], ESD [45], ATXN8OS [46], KFL5 [47], EFNB2 [48], and $\mathrm{PCDH} 8$ [49]. Since it was not possible to narrow down the candidate region of chromosome 13, two genes were chosen for sequence analysis based on their robust association with schizophrenia: DAOA [42] and 5-HTR2A [43]. Protein coding sequence from these two genes, along with $300 \mathrm{bp}$ of upstream non-coding sequence, $300 \mathrm{bp}$ downstream, and at least 25 bp into the splice junctions, were sequenced in patient DNA and compared to canonical sequence (ensemble.org release 61). Five SNPs were identified in the patient, two (rs6313 and rs6311) in 5HTR2A and three (rs1361562, rs2391191, and rs778294) in $D A O A$ [Additional file 4]. In all cases the patient was homozygous for the detected polymorphism, consistent with isodisomy. The patient's father also was found to be homozygous for the 5-HTR2A SNPs rs6313 and rs6311, which are in linkage disequilibrium and are associated with schizophrenia [43]. None of the polymorphisms identified in the patient was novel, and all had been previously described (ensembl.org and ncbi.nlm.nih.gov). None of the polymorphisms noted in the coding regions of either gene was non-synonymous.

\section{Conclusions}

This report describes a patient with isochromosome 13, accompanied by childhood-onset schizophrenia, ADHD 

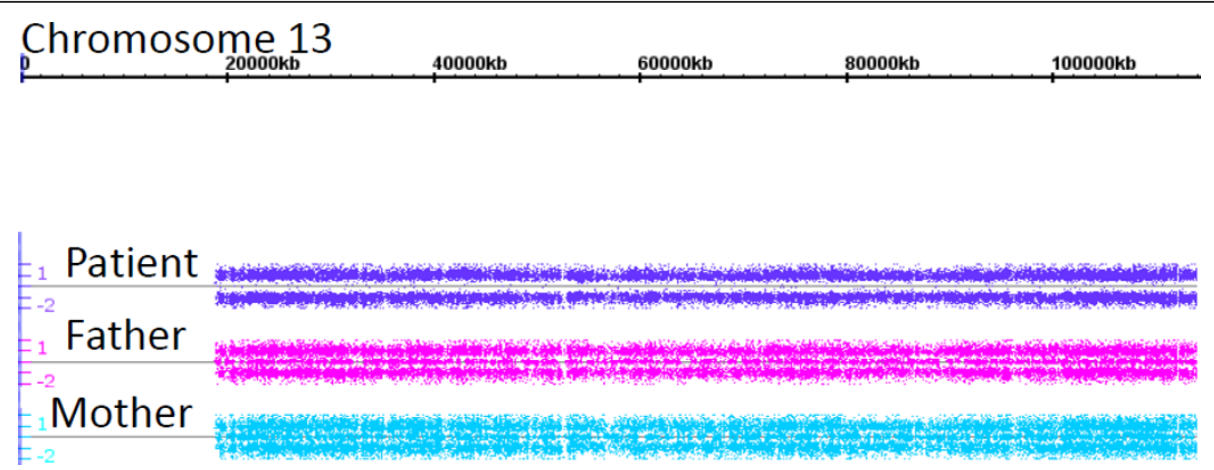

Figure 2 Chromosome 13 Affymetrix Whole-Genome Human SNP 6.0 analysis. Allele analysis demonstrates complete homozygosity of the patient's chromosome 13, with an absence of heterozygous alleles. The patient's parents have both homozygous and heterozygous alleles. Heterozygous markers lie along the center line, while homozygous markers fall either above or below the line.

with hyperactivity and impulsivity, and chronic motor tic disorder. Cytogenetic analysis revealed that the proband carries a 45,XX,i(13)(q10) karyotype, and additional marker analysis demonstrated that the derivative 13 chromosome was a paternally derived isodisomic isochromosome. Since the patient's isochromosome 13 had no evidence of recombination, it most likely formed post-zygotically by monosomy rescue [50]. However, we cannot rule out the possibility that the proband's father is a mosaic carrier of the isochromosome 13. Unless associated with trisomy 13, cases of isochromosome 13 typically do not lead to pathology, although the longterm follow-up needed for detection of mental illness has not typically been reported [51-53]. There are several potential mechanisms by which the proband's isochromosome 13 could lead to the observed pathology.
We were able to examine two of these: reduction to homozygosity of a paternal mutation and reduction to homozygosity of a paternal CNV. The failure to demonstrate either of these leads us to consider whether alternative mechanisms, such as epigenetic regulation, may be responsible for the patient's features.

We initially hypothesized that the patient's father was a heterozygous carrier of a mutation on chromosome 13 that could lead to a phenotype when homozygous in the patient. No overtly pathogenic mutations were detected, although the patient and her father were shown to be homozygous carriers of 5-HTR2A polymorphisms associated with predisposition to schizophrenia (discussed below). We also examined whether the patient exhibited a reduction to homozygosity of a heterozygous chromosome 13 paternal CNV. While several of these small

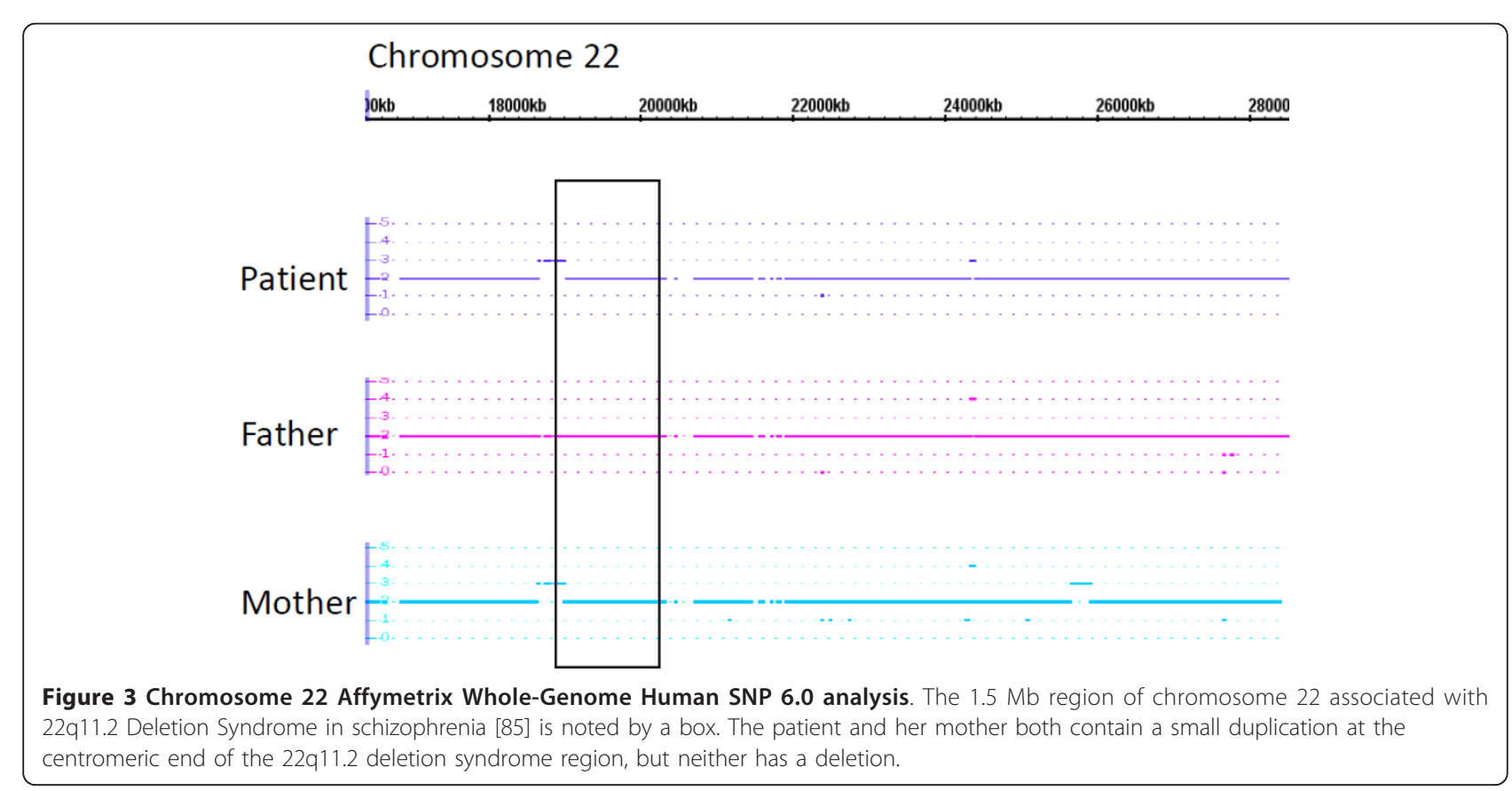




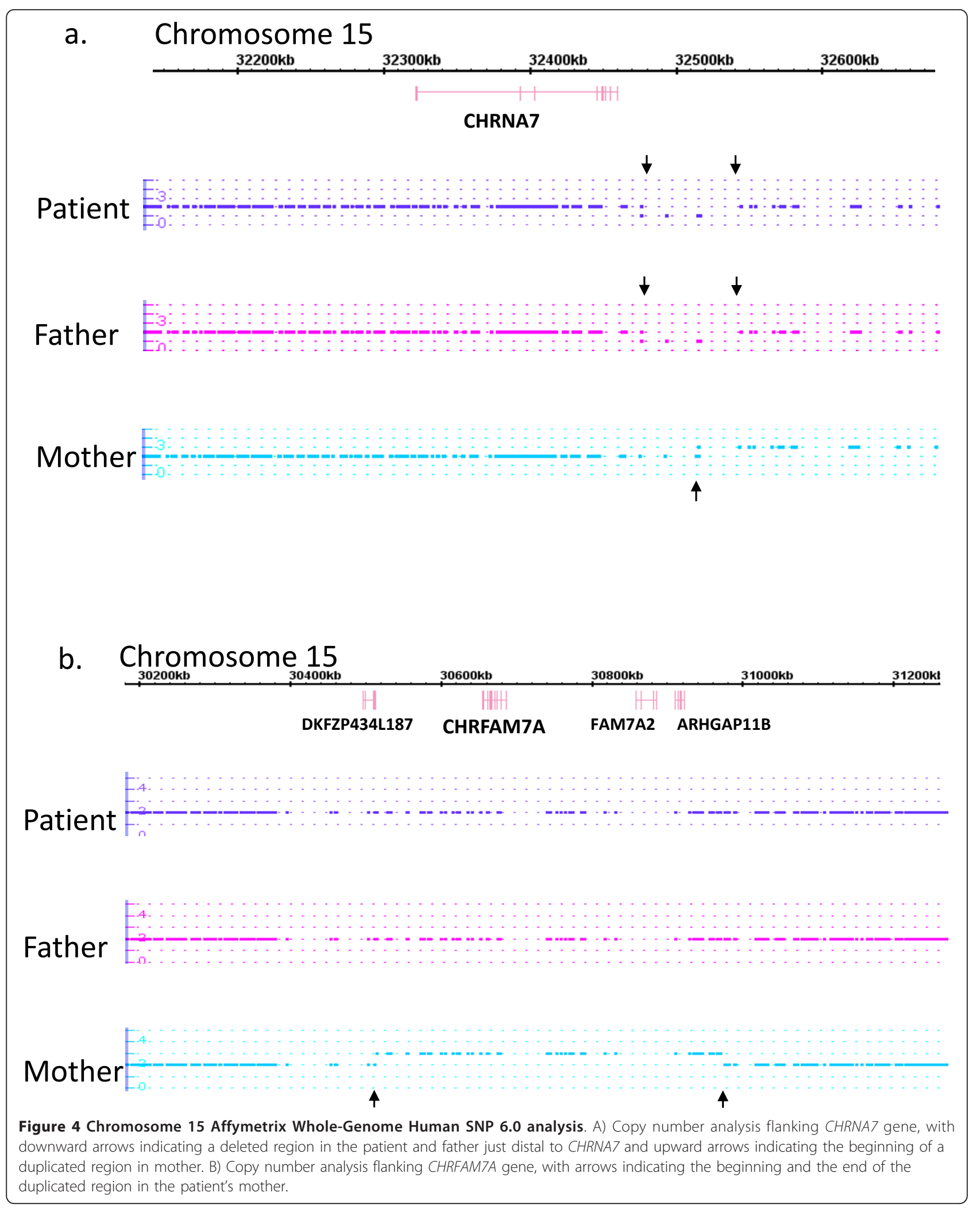


regions were associated with genes, none of these genes is known to be associated with schizophrenia. Thus, chromosome 13 CNVs do not appear to be a robust candidate for her pathology.

We investigated other non-chromosome $13 \mathrm{CNVs}$ and cytogenetic abnormalities. Childhood-onset schizophrenia abnormalities identified by Addington and Rapoport [35] include 22q11, 45,X atypical/mosaic, 47,XXX, duplications of 16p11.2, MYT1L duplication on chromosome 2 , and NRXN1 deletion on chromosome 2. Affymetrix SNP analysis and standard cytogenetics allow us to conclude that this patient has no evidence of the pathologic alterations described by Addington and Rapoport. Similarly, while there was evidence of CNVs on chromosome 15 in the regions associated with schizophrenia, it seems unlikely that chromosome $15 \mathrm{CNVs}$ can account for her severe pathology.

Schizophrenia has been reported in several patients with chromosome 13 rearrangements, and these cases illustrate the difficulty in establishing a causal rather than coincidental relationship between the cytogenetic abnormality and psychiatric pathology. Roberts and coworkers [54] reported an inversion/insertion involving chromosome 13, with breakpoints at 13q21.3, 13q32, and $13 \mathrm{q} 31$, and although the abnormality was found in several family members with "mental subnormality, personality defects and frank psychosis," concordance was not $100 \%$. In this case, pathology may be the result of breakpoint disruption of genes on chromosome 13. Itokawa and coworkers [55] reported a karyotype of 46,XY, $\mathrm{t}(4 ; 13)(\mathrm{p} 16.1 ; \mathrm{q} 21.31)$ in a single patient with a diagnosis of paranoid schizophrenia, and pathology may be associated with disruption of genes on either chromosome 4 or 13. In contrast, schizophrenia in patients with balanced $t(13 ; 14)$, which are common and heterologous, has been reported [56-58], and it is likely that the occurrence of both a chromosome translocation and psychiatric pathology in these patients is coincidental. Thus, while chromosome 13 abnormalities have been found in patients with schizophrenia, it has proven difficult to demonstrate unambiguously that the chromosome abnormality leads to the pathology.

The results presented here lead us to question whether the patient's isochromosome 13 directly leads to her symptoms or is a coincidental finding. Isochromosome 13 is rare [59] and the occurrence of both i (13)(q10) and childhood onset schizophrenia in a single individual would be extremely unlikely. While we have investigated two potential mechanisms by which i (13) (q10) could lead to the patient's pathology, our investigations have not been exhaustive. Mutations in chromosome 13 genes not studied, or in parts of 5HTR $2 A$ or DAOA not sequenced here, may be pathogenic.
There are also additional mechanisms that may be considered. For example, there has been intense speculation concerning the role of epigenetic modification in the susceptibility and development of schizophrenia [60-64]. In cases where the origins have been determined, both maternally and paternally derived uniparental disomy (UPD) of chromosome 13 have been associated with normal development [51-53]. In many cases, however, follow-up has not been extended past childhood, so the possibility of later development of psychiatric pathology cannot be ruled out. There is evidence that regions of chromosome 13 are imprinted in an individual, tissue-specific, or polymorphic fashion, and that regulation may be complex. For example, studies demonstrate allele-specific and parent-of-originspecific differential expression of 5-HTR2A [65-71] and Abdolmaleky and coworkers [72] have found evidence for differences between epigenetic regulation of 5 HTR $2 A$ between patients with schizophrenia or bipolar disorder and controls.

There is precedence for the co-occurrence of uniparental disomy (UPD) and childhood-onset schizophrenia. Seal and coworkers [73] reported a case of childhoodonset schizophrenia associated with segmental UPD of chromosome 5q32-qter. Linkage of schizophrenia to chromosome 5p23.2-p24 has been previously described by multiple groups [74-80], and several candidate genes have been proposed, including the $G A B A$ receptor genes, EPN4 [81], SMAD5, and SPRY4 [82].

The patient described here exhibits childhood-onset schizophrenia, ADHD, and chronic motor tic disorder accompanied by the karyotype 45,XX,i(13)(q10q10). Although we did not find overtly pathogenic chromosome $13 \mathrm{CNVs}$ or mutations in the patient, there may be unidentified mutations in regions of chromosome 13 that were not examined. We did demonstrate that the patient and her father are homozygous carriers of 5-HTR $2 A$ SNPs associated with schizophrenia. Considering the complete homozygosity and UPD of the patient's chromosome 13, epigenetic modifications should be investigated as a potential explanation for the patient's findings.

\section{Methods}

\section{Patient Recruitment}

The patient originally was identified requiring treatment for psychosis, and patient and family material and information were collected as part of an ongoing study which includes cytogenetic analysis of children with psychotic symptoms. Informed consent and assent were obtained as monitored by a local Institutional Review Board.

\section{Cytogenetics}

Cytogenetic analysis of peripheral blood lymphocytes was conducted by the Colorado Genetics Laboratory 
using standard techniques. Following two days in RPMI/ $10 \%$ fetal bovine serum, cultures were exposed to a final concentration of 0.06 micrograms $/ \mathrm{mL}$ of Colcemid (Irvine Scientific, Santa Ana, CA) for $30 \mathrm{~min}-2 \mathrm{hr}$ in order to capture metaphase cells. Cells were exposed to $0.075 \mathrm{M} \mathrm{KCl}$ hypotonic for $30 \mathrm{~min}$ and fixed in 3:1 methanol:glacial acetic acid. Trypsin G-banding was performed following standard procedures [83].

\section{Fluorescence in situ hybridization (FISH)}

FISH analysis utilized an alpha satellite probe with homology to the centromeric heterochromatic regions of chromosomes 13 and 21. FISH analysis for the DiGeorge/Velocardiofacial syndrome (VCSF) critical region at chromosome 22q11.2 was performed with the DiGeorge/VCFS Tuple1 probe using standard methods (Abbott Molecular, Abbott Park, Illinois).

\section{Simple Tandem Repeats (STRs)}

Polymerase Chain Reaction was performed with Taq Gold (Applied Biosystems, Foster City, CA) using primers designed from UniSTS http://ncbi.nlm.nih.gov/ unists on a GeneAmp 9700 thermal cycler (Applied Biosystems, Inc., Foster City, CA). Products were analyzed on an Applied Biosystem's 3100 Avant Genetic Analyzer, and results interpreted with GeneMapper version 3.5 (Applied Biosystem, Inc.). DNA was purified by phenol extraction from lymphoblasts using standard protocols [84].

\section{Affymetrix GenomeWide 6.0 SNP microarrays}

The Affymetrix Genome-Wide Human SNP 6.0 assay was performed according to the manufacturer's instructions (Affymetrix, Santa Clara, CA) in the Genomics and Microarray Core Laboratory at the University of Colorado School of Medicine. Data were combined with HapMap samples provided by Affymetrix and analyzed using the Affymetric Genotyping Console version 4.0. Algorithms for copy number calling are based on the Hidden-Markoff Model, where copy number patterns of neighboring markers are taken into account.

\section{Gene Sequence Analysis}

Genomic sequences and intron/exon structure for Damino acid oxidase activator (DAOA; ENSG00000192346) and 5-hydroxytryptamine (serotonin) receptor 2A (5-HTR2A; ENSG00000102468) were taken from Ensembl Release 61 - Feb 2011 and earlier releases http://ensembl.org, and were used to generate primers for PCR and sequencing with the program Primer3 http://frodo.wi.mit.edu/. Products were sequenced directly without additional purification using the BigDye ${ }^{\circledR}$ Terminator v3.1 Cycle Sequence Kit (Applied Biosystems, Austin, TX) on an ABI 3100-Avant Genetic
Analyzer (Applied Biosystems, Inc.), and analyzed with Sequencher 4.8 (Gene Codes Corporation, Ann Arbor MI). Subject sequences were compared to database sequences using Basic Local Alignment Search Tool (BLAST) http://www.ncbi.nlm.nih.gov/BLAST/.

\section{Consent}

Written informed consent was obtained from the patient's parents for publication of this Case Report. A copy of the written consent is available for review by the Editor-in-Chief of this journal.

\section{Additional material}

Additional file 1: Chromosome 13 CNV analysis of patient and father. CNV analysis indicates the presence of two copies of almost all chromosome 13 markers in the patient and her father.

Additional file 2: Affymetrix Whole-Genome Human SNP6.0 CNV analysis of $M Y T 1 L$ and $N R X N 1$ genes. Analysis indicates that the patient and her parents have two copies of the MYT1L and NRXN1 genes. Additional file 3: Affymetrix Whole-genome Human SNP6.0 analysis of chromosome 16. Analysis indicates that the patient and her parents have regions on chromosome 16 with reduced heterozygosity, and that no significant deletions or duplications are found.

Additional file 4: SNP analysis. SNPS were detected in DAOA and HTR2A genes of patient.

\section{List of abbreviations}

ADHD: attention deficit hyperactivity disorder; ANK3: ankyrin 3; ATP8A2: ATPase, class I, type 8A, member 2; BLAST: Basic local alignment search tool; bp: base pair; CACNA1C: calcium channel, voltage-dependent, $L$ type, Alpha1C subunit; CHRFAM7A: CHRNA7 (cholinergic receptor, nicotinic, alpha 7, exons 5-10) and FAM7A (family with sequence similarity 7A, exons A-E) fusion; CHRNA7: cholinergic receptor, nicotinic, alpha 7; CNV: copy number variation; COMT: catechol-O-methyltransferase; DAOA: D-amino acid oxidase activator; DISC1: disrupted in schizophrenia 1; DSM-IV: Diagnostic and Statistical Manual of Mental Disorders, $4^{\text {th }}$ edition; DTNBP1: dystrobrevin binding protein 1; EPN4: epsin 4; FISH: fluorescence in situ hybridization; GABA: gamma-aminobutyric acid; GAD1: glutamate decarboxylase 1; GRM3: glutamate receptor, metabotropic 3; HTR2A: 5-hydroxytryptamine (serotonin) receptor 2A; ITIH3: inter-alpha-trypsin inhibitor, heavy chain 3; ITIH4: interalpha-trypsin inhibitor, heavy chain 4; LHFP: lipoma HMGIC fusion partner; LOH: loss of heterozygosity; MYT1L: myelin transcription factor 1-like; NRG1: neuregulin 1; NRXN1: neurexin 1; PCR: polymerase chain reaction; PHF11: PHD finger protein 11; PIBF1: C13orf24; progesterone-induced blocking factor 1; PLAA : phospholipase A2-activating protein; PRODH: proline dehydrogenase (oxidase) 2; RCBTB1: Regulator of chromosome condensation $(R C C 1)$ and BTB (POZ) domain contain protein 1; SMAD5: mothers against decapentaplegic, drosophila, homolog of, 5; SNP: single nucleotide polymorphism; SPRY4: sprout, drosophila, homolog of, 4; STR: simple tandem repeat; UPD: uniparental disomy; UTR: untranslated region; VCFS: velocardiofacial syndrome; ZNF804A: zinc finger protein 804A

\section{Acknowledgements}

We would like to thank Robert Freedman for his helpful suggestions and critical reading of this manuscript. This work was supported by $\mathrm{NIH}$ grants MH081177 and DA09457, and the Veterans Affairs Medical Research Service.

\section{Author details}

'Department of Psychiatry, University of Colorado School of Medicine, Aurora, CO, USA. ${ }^{2}$ Colorado Genetics Laboratory, Department of Pathology, University of Colorado School of Medicine, Aurora, CO, USA. ${ }^{3}$ Department of Psychiatry and Behavioral Science, Children's Hospital Colorado, Aurora, CO, 
USA. ${ }^{4}$ Research Division, Veterans Affairs Medical Research Service, Denver, CO, USA.

\section{Authors' contributions}

SG conceived of the study and its design, performed the sequencing, and analyzed the data, and wrote the manuscript. KS supervised the cytogenetic analysis. KF performed the STR analysis. BJC performed the cytogenetic analysis. MZW and RGR examined the patient and provided clinical details. SL participated in study design and data analysis. All authors read and approved the final manuscript.

\section{Competing interests}

The authors declare that they have no competing interests.

Received: 25 August 2011 Accepted: 3 January 2012

Published: 3 January 2012

\section{References}

1. American Psychiatric Association: Diagnostic and statistical manual of mental disorders Washington, D.C.; 1994.

2. Cannon M, Jones $\mathrm{P}$, Huttunen MO, Tanskanen A, Huttunen T, RabeHesketh S, Murray RM: School performance in Finnish children and later development of schizophrenia: a population-based longitudinal study. Arch Gen Psychiatry 1999, 56:457-463.

3. Ross RG, Olincy A, Harris JG, Radant A, Hawkins M, Adler LE, Freedman R: Evidence for bilineal inheritance of physiological indicators of risk in childhood-onset schizophrenia. Am J Med Genet 1999, 88:188-199.

4. Kyriakopoulos M, Frangou S: Pathophysiology of early onset schizophrenia. Int Rev Psychiatry 2007, 19:315-324.

5. Leonard S, Freedman R: Genetics of chromosome 15q13-q14 in schizophrenia. Biol Psychiatry 2006, 60:115-122.

6. Muller DJ, Zai CC, Shinkai T, Strauss J, Kennedy JL: Association between the DAOA/G72 gene and bipolar disorder and meta-analyses in bipolar disorder and schizophrenia. Bipolar Disord 2011, 13:198-207.

7. Harrison PJ, Weinberger DR: Schizophrenia genes, gene expression, and neuropathology: on the matter of their convergence. Mol Psychiatry 2005, 10:40-68.

8. Athanasiu L, Mattingsdal M, Kahler AK, Brown A, Gustafsson O, Agartz I, Giegling I, Muglia P, Cichon S, Rietschel M, Pietilainen OP, Peltonen L, Bramon E, Collier D, Clair DS, Sigurdsson E, Petursson H, Rujescu D, Melle I, Steen VM, Djurovic S, Andreassen OA: Gene variants associated with schizophrenia in a Norwegian genome-wide study are replicated in a large European cohort. J Psychiatr Res 2010, 44:748-753.

9. Purcell SM, Wray NR, Stone JL, Visscher PM, O'Donovan MC, Sullivan PF, Sklar P: Common polygenic variation contributes to risk of schizophrenia and bipolar disorder. Nature 2009, 460:748-752.

10. Kirov G, Zaharieva I, Georgieva L, Moskvina V, Nikolov I, Cichon S, Hillmer A, Toncheva D, Owen MJ, O'Donovan MC: A genome-wide association study in 574 schizophrenia trios using DNA pooling. Mol Psychiatry 2009, 14:796-803.

11. Lencz T, Morgan TV, Athanasiou M, Dain B, Reed CR, Kane JM, Kucherlapati R, Malhotra AK: Converging evidence for a pseudoautosomal cytokine receptor gene locus in schizophrenia. Mol Psychiatry 2007, 12:572-580.

12. Liu Y, Chen G, Norton N, Liu W, Zhu H, Zhou P, Luan M, Yang S, Chen X, Carroll L, Williams NM, O'Donovan MC, Kirov G, Owen MJ: Whole genome association study in a homogenous population in Shandong peninsula of China reveals JARID2 as a susceptibility gene for schizophrenia. J Biomed Biotechnol 2009, 2009:536918.

13. Mah S, Nelson MR, Delisi LE, Reneland RH, Markward N, James MR, Nyholt DR, Hayward N, Handoko H, Mowry B, Kammerer S, Braun A: Identification of the semaphorin receptor PLXNA2 as a candidate for susceptibility to schizophrenia. Mol Psychiatry 2006, 11:471-478.

14. Need AC, Ge D, Weale ME, Maia J, Feng S, Heinzen EL, Shianna KV, Yoon W, Kasperaviciute D, Gennarelli M, Strittmatter WJ, Bonvicini C, Rossi G, Jayathilake K, Cola PA, McEvoy JP, Keefe RS, Fisher EM, St Jean PL, Giegling I, Hartmann AM, Moller HJ, Ruppert A, Fraser G, Crombie C, Middleton LT, St CD, Roses AD, Muglia P, Francks C, et al: A genome-wide investigation of SNPs and CNVs in schizophrenia. PLoS Genet 2009, 5: e1000373.
15. Shi J, Levinson DF, Duan J, Sanders AR, Zheng Y, Pe'er I, Dudbridge F, Holmans PA, Whittemore AS, Mowry BJ, Olincy A, Amin F, Cloninger CR, Silverman JM, Buccola NG, Byerley WF, Black DW, Crowe RR, Oksenberg JR, Mirel DB, Kendler KS, Freedman R, Gejman PV: Common variants on chromosome 6p22.1 are associated with schizophrenia. Nature 2009, 460:753-757.

16. Shifman S, Johannesson $M$, Bronstein $M$, Chen SX, Collier DA, Craddock NJ, Kendler KS, Li T, O'Donovan M, O'Neill FA, Owen MJ, Walsh D, Weinberger DR, Sun C, Flint J, Darvasi A: Genome-wide association identifies a common variant in the reelin gene that increases the risk of schizophrenia only in women. PLoS Genet 2008, 4:e28.

17. Stefansson H, Ophoff RA, Steinberg S, Andreassen OA, Cichon S, Rujescu D, Werge T, Pietilainen OP, Mors O, Mortensen PB, Sigurdsson E, Gustafsson O, Nyegaard M, Tuulio-Henriksson A, Ingason A, Hansen T, Suvisaari J, Lonnqvist J, Paunio T, Borglum AD, Hartmann A, Fink-Jensen A, Nordentoft M, Hougaard D, Norgaard-Pedersen B, Bottcher Y, Olesen J, Breuer R, Moller HJ, Giegling I, et al: Common variants conferring risk of schizophrenia. Nature 2009, 460:744-747.

18. Sullivan PF: The psychiatric GWAS consortium: big science comes to psychiatry. Neuron 2010, 68:182-186.

19. O'Donovan MC, Craddock N, Norton N, Williams H, Peirce T, Moskvina V, Nikolov I, Hamshere M, Carroll L, Georgieva L, Dwyer S, Holmans P, Marchini JL, Spencer CC, Howie B, Leung HT, Hartmann AM, Moller HJ, Morris DW, Shi Y, Feng G, Hoffmann P, Propping P, Vasilescu C, Maier W, Rietschel M, Zammit S, Schumacher J, Quinn EM, Schulze TG, et al: Identification of loci associated with schizophrenia by genome-wide association and follow-up. Nat Genet 2008, 40:1053-1055.

20. Potkin SG, Turner JA, Guffanti G, Lakatos A, Fallon JH, Nguyen DD, Mathalon D, Ford J, Lauriello J, Macciardi F: A genome-wide association study of schizophrenia using brain activation as a quantitative phenotype. Schizophr Bull 2009, 35:96-108.

21. Ripke S, Sanders AR, Kendler KS, Levinson DF, Sklar P, Holmans PA, Lin DY Duan J, Ophoff RA, Andreassen OA, Scolnick E, Cichon S, St CD, Corvin A, Gurling H, Werge T, Rujescu D, Blackwood DH, Pato CN, Malhotra AK, Purcell S, Dudbridge F, Neale BM, Rossin L, Visscher PM, Posthuma D, Ruderfer DM, Fanous A, Stefansson H, Steinberg S, et al: Genome-wide association study identifies five new schizophrenia loci. Nat Genet 2011, 43:969-976.

22. Stefansson H, Rujescu D, Cichon S, Pietilainen OP, Ingason A, Steinberg S, Fossdal R, Sigurdsson E, Sigmundsson T, Buizer-Voskamp JE, Hansen T, Jakobsen KD, Muglia P, Francks C, Matthews PM, Gylfason A, Halldorsson BV, Gudbjartsson D, Thorgeirsson TE, Sigurdsson A, Jonasdottir A, Jonasdottir A, Bjornsson A, Mattiasdottir S, Blondal T, Haraldsson M, Magnusdottir BB, Giegling I, Moller HJ, Hartmann A, et al: Large recurrent microdeletions associated with schizophrenia. Nature 2008, 455:232-236

23. McCarthy SE, Makarov V, Kirov G, Addington AM, McClellan J, Yoon S, Perkins DO, Dickel DE, Kusenda M, Krastoshevsky O, Krause V, Kumar RA, Grozeva D, Malhotra D, Walsh T, Zackai EH, Kaplan P, Ganesh J, Krantz ID, Spinner NB, Roccanova P, Bhandari A, Pavon K, Lakshmi B, Leotta A, Kendall J, Lee YH, Vacic V, Gary S, lakoucheva LM, et al: Microduplications of 16p11.2 are associated with schizophrenia. Nat Genet 2009, 41:1223-1227.

24. Levinson DF, Duan J, Oh S, Wang K, Sanders AR, Shi J, Zhang N, Mowry BJ, Olincy A, Amin F, Cloninger CR, Silverman JM, Buccola NG, Byerley WF, Black DW, Kendler KS, Freedman R, Dudbridge F, Pe'er I, Hakonarson H, Bergen SE, Fanous AH, Holmans PA, Gejman PV: Copy number variants in schizophrenia: confirmation of five previous findings and new evidence for 3q29 microdeletions and VIPR2 duplications. Am J Psychiatry 2011 168:302-316

25. International Schizophrenia Consortium: Rare chromosomal deletions and duplications increase risk of schizophrenia. Nature 2008, 455:237-241.

26. Brown AS, Derkits EJ: Prenatal infection and schizophrenia: a review of epidemiologic and translational studies. Am J Psychiatry 2010, 167:261-280.

27. Wicks S, Hjern A, Dalman C: Social risk or genetic liability for psychosis? A study of children born in Sweden and reared by adoptive parents. Am J Psychiatry 2010, 167:1240-1246.

28. Dragt $\mathrm{S}$, Nieman $\mathrm{DH}$, Veltman $\mathrm{D}$, Becker $\mathrm{HE}$, van de Fliert $\mathrm{R}$, de $\mathrm{HL}$, Linszen DH: Environmental factors and social adjustment as predictors of 
a first psychosis in subjects at ultra high risk. Schizophr Res 2011, 125:69-76.

29. Andreasson S, Allebeck P, Engstrom A, Rydberg U: Cannabis and schizophrenia. A longitudinal study of Swedish conscripts. Lancet 1987, 2:1483-1486.

30. Yue W, Liu Z, Kang G, Yan J, Tang F, Ruan Y, Zhang J, Zhang D: Association of $\mathrm{G} 72 / \mathrm{G} 30$ polymorphisms with early-onset and male schizophrenia. Neuroreport 2006, 17:1899-1902.

31. Addington AM, Gornick MC, Shaw P, Seal J, Gogtay N, Greenstein D, Clasen L, Coffey M, Gochman P, Long R, Rapoport JL: Neuregulin 1 (8p12) and childhood-onset schizophrenia: susceptibility haplotypes for diagnosis and brain developmental trajectories. Mol Psychiatry 2007, 12:195-205.

32. Gornick MC, Addington AM, Sporn A, Gogtay N, Greenstein D, Lenane M, Gochman P, Ordonez A, Balkissoon R, Vakkalanka R, Weinberger DR, Rapoport JL, Straub RE: Dysbindin (DTNBP1, 6p22.3) is associated with childhood-onset psychosis and endophenotypes measured by the Premorbid Adjustment Scale (PAS). J Autism Dev Disord 2005, 35:831-838.

33. Straub RE, Jiang Y, MacLean CJ, Ma Y, Webb BT, Myakishev MV, HarrisKerr C, Wormley B, Sadek H, Kadambi B, Cesare AJ, Gibberman A, Wang X, O'Neill FA, Walsh D, Kendler KS: Genetic variation in the 6p22.3 gene DTNBP1, the human ortholog of the mouse dysbindin gene, is associated with schizophrenia. Am J Hum Genet 2002, 71:337-348.

34. Addington AM, Gornick M, Duckworth J, Sporn A, Gogtay N, Bobb A, Greenstein D, Lenane M, Gochman P, Baker N, Balkissoon R, Vakkalanka RK, Weinberger DR, Rapoport JL, Straub RE: GAD1 (2q31.1), which encodes glutamic acid decarboxylase (GAD67), is associated with childhoodonset schizophrenia and cortical gray matter volume loss. Mol Psychiatry 2005, 10:581-588.

35. Addington AM, Rapoport JL: The genetics of childhood-onset schizophrenia: when madness strikes the prepubescent. Curr Psychiatry Rep 2009, 11:156-161.

36. Kaufman J, Birmaher B, Brent D, Rao U, Flynn C, Moreci P, Williamson D, Ryan N: Schedule for Affective Disorders and Schizophrenia for SchoolAge Children-Present and Lifetime Version (K-SADS-PL): initial reliability and validity data. J Am Acad Child Adolesc Psychiatry 1997, 36:980-988.

37. Bassett AS, Chow EW: Schizophrenia and 22q11.2 deletion syndrome. Curr Psychiatry Rep 2008, 10:148-157.

38. Flomen RH, Collier DA, Osborne S, Munro J, Breen G, St CD, Makoff AJ: Association study of CHRFAM7A copy number and 2 bp deletion polymorphisms with schizophrenia and bipolar affective disorder. Am $J$ Med Genet B Neuropsychiatr Genet 2006, , 141B: 571-575.

39. Sinkus ML, Lee MJ, Gault J, Logel J, Short M, Freedman R, Christian SL, Lyon J, Leonard S: A 2-base pair deletion polymorphism in the partial duplication of the alpha7 nicotinic acetylcholine gene (CHRFAM7A) on chromosome 15q14 is associated with schizophrenia. Brain Res 2009, 1291:1-11.

40. Araud T, Graw S, Berger R, Lee M, Neveu E, Bertrand D, Leonard S: The chimeric gene CHRFAM7A, a partial duplication of the CHRNA7 gene, is a dominant negative regulator of alpha7*nAChR function. Biochem Pharmacol 2011, 82:904-914.

41. de Lucas-Cerrillo AM, Maldifassi MC, Arnalich F, Renart J, Atienza G, Serantes R, Cruces J, Sanchez-Pacheco A, Andres-Mateos E, Montiel C: Function of partially duplicated human alpha77 nicotinic receptor subunit CHRFAM7A gene: potential implications for the cholinergic antiinflammatory response. J Biol Chem 2011, 286:594-606.

42. Addington AM, Gornick M, Sporn AL, Gogtay N, Greenstein D, Lenane M, Gochman P, Baker N, Balkissoon R, Vakkalanka RK, Weinberger DR, Straub RE, Rapoport JL: Polymorphisms in the $13 q 33.2$ gene G72/G30 are associated with childhood-onset schizophrenia and psychosis not otherwise specified. Biol Psychiatry 2004, 55:976-980

43. Abdolmaleky HM, Faraone SV, Glatt SJ, Tsuang MT: Meta-analysis of association between the $\mathrm{T} 102 \mathrm{C}$ polymorphism of the $5 \mathrm{HT} 2 \mathrm{a}$ receptor gene and schizophrenia. Schizophr Res 2004, 67:53-62.

44. Zhang H, Ju G, Wei J, Hu Y, Liu L, Xu Q, Chen Y, Sun Z, Liu S, Yu Y, Guo Y, Shen Y: A combined effect of the KPNA3 and KPNB3 genes on susceptibility to schizophrenia. Neurosci Lett 2006, 402:173-175.

45. Fananas L, Moral P, Marti Tusquets $J L$, Bertranpetit J: Genetic markers in schizophrenia: ACP1, ESD, TF and GC polymorphisms. Hum Hered 1990, 40:136-140.
46. Vincent JB, Yuan QP, Schalling M, Adolfsson R, Azevedo MH, Macedo A, Bauer A, DallaTorre C, Medeiros HM, Pato MT, Pato CN, Bowen T, Guy CA, Owen MJ, O'Donovan MC, Paterson AD, Petronis A, Kennedy JL: Long repeat tracts at SCA8 in major psychosis. Am J Med Genet 2000, 96:873-876.

47. Yanagi M, Hashimoto T, Kitamura N, Fukutake M, Komure O, Nishiguchi N, Kawamata T, Maeda K, Shirakawa O: Expression of Kruppel-like factor 5 gene in human brain and association of the gene with the susceptibility to schizophrenia. Schizophr Res 2008, 100:291-301.

48. Zhang R, Zhong NN, Liu XG, Yan H, Qiu C, Han Y, Wang W, Hou WK, Liu Y, Gao CG, Guo TW, Lu SM, Deng HW, Ma J: Is the EFNB2 locus associated with schizophrenia? Single nucleotide polymorphisms and haplotypes analysis. Psychiatry Res 2010, 180:5-9.

49. Bray NJ, Kirov G, Owen RJ, Jacobsen NJ, Georgieva L, Williams HJ, Norton N, Spurlock G, Jones S, Zammit S, O'Donovan MC, Owen MJ: Screening the human protocadherin 8 ( $\mathrm{PCDH} 8)$ gene in schizophrenia. Genes Brain Behav 2002, 1:187-191.

50. Shaffer LG, Lupski JR: Molecular mechanisms for constitutional chromosomal rearrangements in humans. Annu Rev Genet 2000, 34:297-329.

51. Berend SA, Feldman GL, McCaskill C, Czarnecki P, Van Dyke DL, Shaffer LG: Investigation of two cases of paternal disomy 13 suggests timing of isochromosome formation and mechanisms leading to uniparental disomy. Am J Med Genet 1999, 82:275-281.

52. Soler A, Margarit E, Queralt R, Carrio A, Costa D, Gomez D, Ballesta F: Paternal isodisomy 13 in a normal newborn infant after trisomy rescue evidenced by prenatal diagnosis. Am J Med Genet 2000, 90:291-293.

53. Slater H, Shaw JH, Dawson G, Bankier A, Forrest SM: Maternal uniparental disomy of chromosome 13 in a phenotypically normal child. J Med Genet 1994, 31:644-646.

54. Roberts SH, Cowie VA, Singh KR: Intrachromosomal insertion of chromosome 13 in a family with psychosis and mental subnormality. J Ment Defic Res 1986, 30(Pt 3):227-232.

55. Itokawa M, Kasuga T, Yoshikawa T, Matsushita M: Identification of a male schizophrenic patient carrying a de novo balanced translocation, $\mathrm{t}(4 ; 13)$ (p16.1; q21.31). Psychiatry Clin Neurosci 2004, 58:333-337.

56. Escobar Jl: A cytogenetic study of children with psychiatric disorders. Compr Psychiatry 1976, 17:309-313.

57. Price WH, Brunton M, Buckton K, Jacobs PA: Chromosome survey of new patients admitted to the four maximum security hospitals in the United Kingdom. Clin Genet 1976, 9:389-398.

58. Macintyre DJ, Blackwood DH, Porteous DJ, Pickard BS, Muir WJ: Chromosomal abnormalities and mental illness. Mol Psychiatry 2003, 8:275-287.

59. Chen CP, Chern SR, Wu PC, Tsai FJ, Lee CC, Town DD, Chen WL, Chen LF, Lee MS, Pan CW, Wang W: Unbalanced and balanced acrocentric rearrangements involving chromosomes other than chromosome 21 at amniocentesis. Taiwan J Obstet Gynecol 2009, 48:389-399.

60. Pidsley R, Mill J: Epigenetic studies of psychosis: current findings, methodological approaches, and implications for postmortem research. Biol Psychiatry 2011, 69:146-156.

61. Perrin M, Kleinhaus K, Messinger J, Malaspina D: Critical periods and the developmental origins of disease: an epigenetic perspective of schizophrenia. Ann N Y Acad Sci 2010, 1204 Suppl: E8-13.

62. Brown AS: The environment and susceptibility to schizophrenia. Prog Neurobiol 2011, 93:23-58.

63. Akbarian S: Epigenetics of schizophrenia. Curr Top Behav Neurosci 2010, 4:611-628.

64. Lester BM, Tronick E, Nestler E, Abel T, Kosofsky B, Kuzawa CW, Marsit CJ, Maze I, Meaney MJ, Monteggia LM, Reul JM, Skuse DH, Sweatt JD, Wood MA: Behavioral epigenetics. Ann N Y Acad Sci 2011, 1226:14-33.

65. Bunzel R, Blumcke I, Cichon S, Normann S, Schramm J, Propping P, Nothen MM: Polymorphic imprinting of the serotonin-2A (5-HT2A) receptor gene in human adult brain. Brain Res Mol Brain Res 1998, 59:90-92.

66. Kato MV, Shimizu T, Nagayoshi M, Kaneko A, Sasaki MS, Ikawa Y: Genomic imprinting of the human serotonin-receptor (HTR2) gene involved in development of retinoblastoma. Am J Hum Genet 1996, 59:1084-1090.

67. Kato MV, Ikawa $Y$, Hayashizaki $Y$, Shibata $H$ : Paternal imprinting of mouse serotonin receptor $2 \mathrm{~A}$ gene $\mathrm{Htr} 2$ in embryonic eye: a conserved imprinting regulation on the RB/Rb locus. Genomics 1998, 47:146-148. 
68. Fukuda Y, Koga M, Arai M, Noguchi E, Ohtsuki T, Horiuchi Y, Ishiguro H, Niizato K, Iritani S, Itokawa M, Arinami T: Monoallelic and unequal allelic expression of the HTR2A gene in human brain and peripheral lymphocytes. Biol Psychiatry 2006, 60:1331-1335.

69. Bray NJ, Buckland PR, Hall H, Owen MJ, O'Donovan MC: The serotonin-2A receptor gene locus does not contain common polymorphism affecting mRNA levels in adult brain. Mol Psychiatry 2004, 9:109-114.

70. Polesskaya OO, Aston C, Sokolov BP: Allele C-specific methylation of the 5-HT2A receptor gene: evidence for correlation with its expression and expression of DNA methylase DNMT1. J Neurosci Res 2006, 83:362-373.

71. Polesskaya OO, Sokolov BP: Differential expression of the " $\mathrm{C}$ " and " $\mathrm{T}$ " alleles of the $5-\mathrm{HT} 2 \mathrm{~A}$ receptor gene in the temporal cortex of normal individuals and schizophrenics. J Neurosci Res 2002, 67:812-822.

72. Abdolmaleky HM, Yaqubi S, Papageorgis $P$, Lambert AW, Ozturk S, Sivaraman $V$, Thiagalingam S: Epigenetic dysregulation of HTR2A in the brain of patients with schizophrenia and bipolar disorder. Schizophr Res 2011, 129:183-190.

73. Seal JL, Gornick MC, Gogtay N, Shaw P, Greenstein DK, Coffey M, Gochman PA, Stromberg T, Chen Z, Merriman B, Nelson SF, Brooks J, Arepalli S, Wavrant-De VF, Hardy J, Rapoport JL, Addington AM: Segmental uniparental isodisomy on $5 q 32$-qter in a patient with childhood-onset schizophrenia. J Med Genet 2006, 43:887-892.

74. Straub RE, MacLean CJ, O'Neill FA, Walsh D, Kendler KS: Support for a possible schizophrenia vulnerability locus in region 5q22-31 in Irish families. Mol Psychiatry 1997, 2:148-155.

75. Lewis CM, Levinson DF, Wise LH, Delisi LE, Straub RE, Hovatta I, Williams NM, Schwab SG, Pulver AE, Faraone SV, Brzustowicz LM, Kaufmann CA, Garver DL, Gurling HM, Lindholm E, Coon H, Moises HW, Byerley W, Shaw SH, Mesen A, Sherrington R, O'Neill FA, Walsh D, Kendler KS, Ekelund J, Paunio T, Lonnqvist J, Peltonen L, O'Donovan MC, Owen MJ, et al: Genome scan meta-analysis of schizophrenia and bipolar disorder, part II: Schizophrenia. Am J Hum Genet 2003, 73:34-48.

76. Gurling HM, Kalsi G, Brynjolfson J, Sigmundsson T, Sherrington R, Mankoo BS, Read T, Murphy P, Blaveri E, McQuillin A, Petursson H, Curtis D: Genomewide genetic linkage analysis confirms the presence of susceptibility loci for schizophrenia, on chromosomes 1q32.2, 5q33.2, and 8p21-22 and provides support for linkage to schizophrenia, on chromosomes 11q23.3-24 and 20q12.1-11.23. Am J Hum Genet 2001, 68:661-673.

77. Schwab SG, Eckstein GN, Hallmayer J, Lerer B, Albus M, Borrmann M, Lichtermann D, Ertl MA, Maier W, Wildenauer DB: Evidence suggestive of a locus on chromosome 5 q31 contributing to susceptibility for schizophrenia in German and Israeli families by multipoint affected sibpair linkage analysis. Mol Psychiatry 1997, 2:156-160.

78. Paunio T, Ekelund J, Varilo T, Parker A, Hovatta I, Turunen JA, Rinard K, Foti A, Terwilliger JD, Juvonen H, Suvisaari J, Arajarvi R, Suokas J, Partonen T, Lonnqvist J, Meyer J, Peltonen L: Genome-wide scan in a nationwide study sample of schizophrenia families in Finland reveals susceptibility loci on chromosomes 2q and 5q. Hum Mol Genet 2001, 10:3037-3048.

79. Devlin B, Bacanu SA, Roeder K, Reimherr F, Wender P, Galke B, Novasad D, Chu A, TCuenco K, Tiobek S, Otto C, Byerley W: Genome-wide multipoint linkage analyses of multiplex schizophrenia pedigrees from the oceanic nation of Palau. Mol Psychiatry 2002, 7:689-694.

80. Sklar P, Pato MT, Kirby A, Petryshen TL, Medeiros H, Carvalho C, Macedo A, Dourado A, Coelho I, Valente J, Soares MJ, Ferreira CP, Lei M, Verner A, Hudson TJ, Morley CP, Kennedy JL, Azevedo MH, Lander E, Daly MJ, Pato CN: Genome-wide scan in Portuguese Island families identifies 5q31-5q35 as a susceptibility locus for schizophrenia and psychosis. Mol Psychiatry 2004, 9:213-218.

81. Pimm J, McQuillin A, Thirumalai S, Lawrence J, Quested D, Bass N, Lamb G, Moorey H, Datta SR, Kalsi G, Badacsonyi A, Kelly K, Morgan J, Punukollu B, Curtis D, Gurling H: The Epsin 4 gene on chromosome 5q, which encodes the clathrin-associated protein enthoprotin, is involved in the genetic susceptibility to schizophrenia. Am J Hum Genet 2005, 76:902-907.

82. Zaharieva I, Georgieva L, Nikolov I, Kirov G, Owen MJ, O'Donovan MC, Toncheva D: Association study in the 5q31-32 linkage region for schizophrenia using pooled DNA genotyping. BMC Psychiatry 2008, 8:11.

83. Gustashaw KM: Chromosome stains. In The AGT cytogenetic laboratory manual.. 3 edition. Edited by: Barch,MJ, Knutsen, T., and Spurbeck, J. L. Philadelphia: Lippincott-Raven; 1997:269-280.
84. Sambrook J, Russell DW: Molecular Cloning A Laboratory Manual Cold Spring Harbor, New York: Cold Spring Harbor Laboratory Press; 2001.

85. Karayiorgou M, Simon TJ, Gogos JA: 22q11.2 microdeletions: linking DNA structural variation to brain dysfunction and schizophrenia. Nat Rev Neurosci 2010, 11:402-416.

\section{doi:10.1186/1755-8166-5-2}

Cite this article as: Graw et al:: Isochromosome 13 in a patient with childhood-onset schizophrenia, ADHD, and motor tic disorder. Molecular Cytogenetics 2012 5:2

\section{Submit your next manuscript to BioMed Central and take full advantage of:}

- Convenient online submission

- Thorough peer review

- No space constraints or color figure charges

- Immediate publication on acceptance

- Inclusion in PubMed, CAS, Scopus and Google Scholar

- Research which is freely available for redistribution

Submit your manuscript at www.biomedcentral.com/submit
Biomed Central 